ABORIGINAL HISTORY 1989 13:2

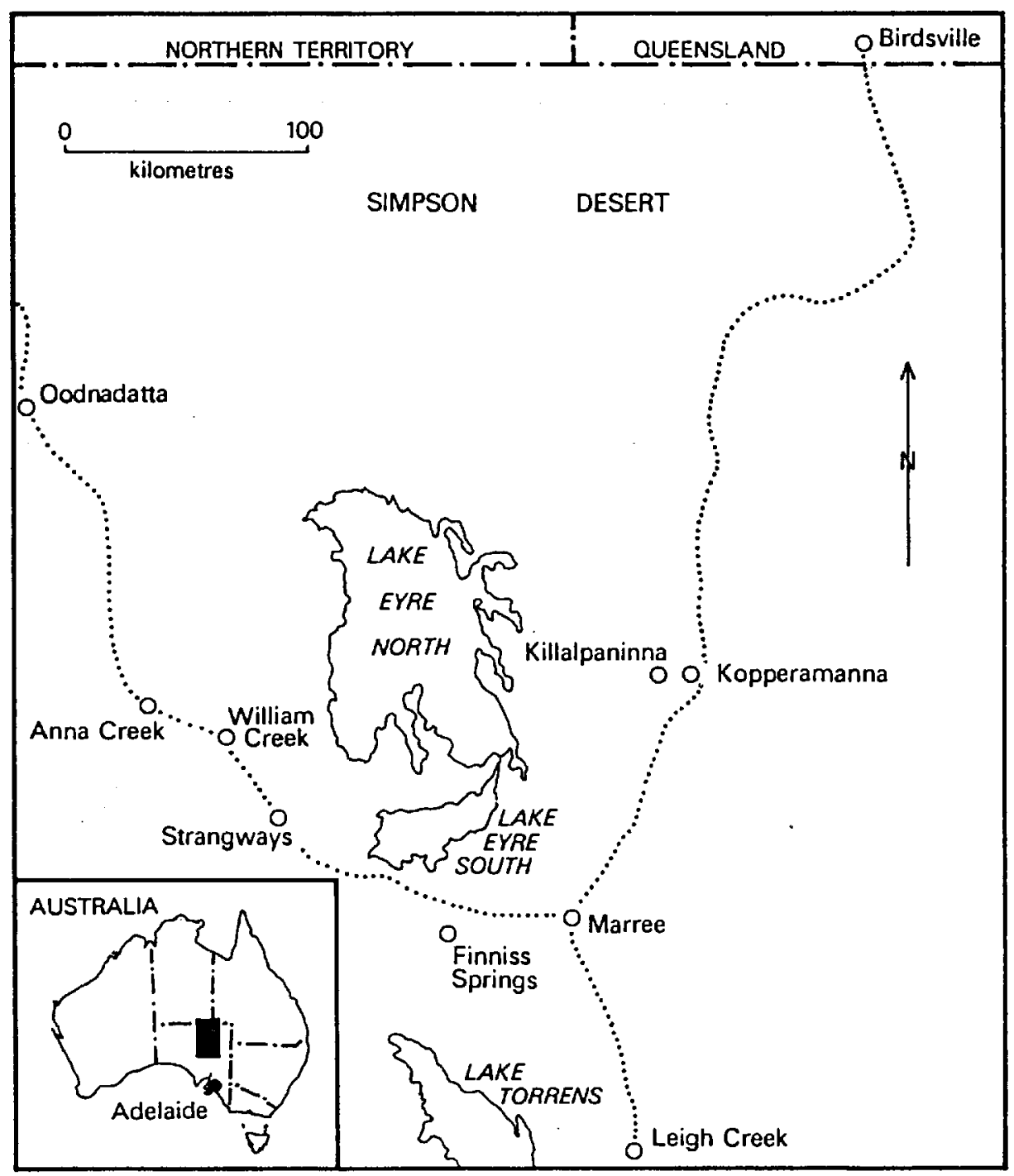

Finniss Springs Region, South Australia [John Heyward, Cartographic Unit, RSPacS] 


\title{
LEARNING TIMES An experience of Arabana life and mission education
}

\author{
Reg Dodd and Jen Gibson
}

\section{Introduction}

Mission experiences in Aboriginal history have been divers and controversial. The situation at Finniss Springs South Australia combining pastoral station and mission brings its own unique variation to this theme. Although the environment was harsh and the situation demanded continual adjustment to climatic extremes of flood and drought, the memories of the children growing up at Finniss from the late 1930s onwards are of 'happy times' and 'learning times'. 1 They are not filled with bitterness and repression as so often is the case. By this time mission approaches had 'mellowed'. The complete removal of children from relatives and culture which occurred in the 1920s around Oodnadatta was ceasing. The influence of one European man, Francis Dunbar Warren, in a position to facilitate his younger Aboriginal friends and relatives receiving a western education within a pastoral environment, complementing that received from their own extended families, was also crucial.

The Warrens and the Hogarths are early pastoral families in South Australia interconnected by marriage. They first acquired a pastoral lease at Strangways Springs between Marree and Oodnadatta in 1863 and then shifted to nearby Anna Creek Station. 2 When the family sold Anna Creek in 1918, Francis Dunbar Warren who had been the manager for his uncle Hogarth was forced to leave. Warren already had several children and was determined to keep them and Bralda their mother, with him. ${ }^{3}$ To do this he realised he would have to find another pastoral station in the inhospitable inland areas.

Reg Dodd is the Chairman of the Marree Arabana People's Committee, South Australia. He works with the National Parks and Wildlife Division of the Department of Environment and Planning, South Australia and is based at Marree.

Jen Gibson was research assistant and a tutor in anthropology at the University of Western Australia. For ten years she taught and lectured in Montessori education. For three years she worked for the Oodnadatta Aboriginal community. Currently she is a research scholar with the Australian Institute of Aboriginal Studies working in the Marree region of South Australia.

1 Personal communications 1987 and 1988, Reg Dodd, Jean Wood nee Arkaringa, Norman Wood, Lance Warren, Merna Merrick, Doreen and Laurie Stuart, Robert Pearce and others. Also see Rhonda Dodd's memories in E. Kwan 1988:79-82.

2 Warren 1930:17 gives the year for the settlement of Strangways as 1863. The Adelaide Advertiser Saturday, October 29, 1988 states that with 32,000 square kilometres Anna Creek Station in the far north of South Australia is the largest cattle station in the world. Aboriginal stockmen have always been vital to its survival.

3 Basedow 1921:23 list her as Barralda a half-caste whose European name is Laura an Arrabanna from Finniss Springs. None of her descendants remember the name Laura and only very few her Aboriginal name. 
Mrs Merna Merrick, ${ }^{4}$ Francis Warren's oldest surviving child, was a young girl of about eight years old at this time. Her father resolved that at all costs they should not be taken away. South Australian government policy of that day as elsewhere in Australia called for the removal of 'half-caste' children. 5 In partnership with William 'Bill' Wood (a former book keeper at Anna Creek), Francis used his share of money from the sale to purchase Finniss Springs Station near Lake Eyre South and sixty kilometres west of Marree. ${ }^{6}$ Warren and his family first stopped at the site of the ruins of original Finniss Springs homestead built in the 1860s. Within a few years the sand flies and mosquitoes drove them away from the springs. In 1922 Warren built a lovely stone house at Deep Creek and made it his head station. Thi was originally called New Finniss but it is what Reg and people in the area today refer to as Finniss Springs Station or simply Finniss.

Many Aboriginal families moved to Finniss with Francis Dunbar Warren who managed to survive on this economically marginal property distributing rations and occasionally fresh meat to them. ${ }^{7}$ Apart from the general coming and going associated with outside jobs, most of these families stayed there until his death in the 1950s so great was their attachment to the family and subsequently the place.

By the mid-1930s there were many more children being born and living at Finniss Springs. The German missionaries particularly Hermann Vogelsang formerly from Killalpaninna made several visit between 1934 and his death in 1940 the most extensive being in $1937 .{ }^{8}$ Many of the Diyeri people from Killalpaninna had moved there following the closure of these Lutheran missions on the Birdsville track, including Merna's husband Alf Merrick ${ }^{9}$ The children were not receiving a western education. A subsequent report by Mr Telfer a Methodist missionary to the United Aborigines Mission in Adelaide expressed a perceived urgent need for a Christian education for the children at Finniss.

Since 1924 the United Aborigines Mission had had a presence in the north of South Australia firstly at Oodnadatta. From there camel expeditions had travelled northwest to contact Aboriginal people. A mission home at Oodnadatta had moved to Quorn in 1927 where it continued throughout this period. ${ }^{10}$ Older siblings of some of the Finniss Springs children were educated at the UAM's Colebrook Home in Quom. Here they lost their own

4 Mona is an equally acceptable anglicising of this name which comes from the Arabana word mana meaning mouth. Mrs Merrick herself had no preference, personal communications April 1988. However, after a night's thought she did recall that her given name by her father was Lena.

5 'I think that all "half-caste" children at least could be gathered in, instead of being left in the camp', S.a. Protector of Aborigines Annual Report 1908:107. Compare the circumstances of Molly Lennon in Gibson \& Sennon 1989:23f.

6 Pearce, 1980 p.188f.

7 Most of the Aboriginal people who moved with him were of Arabana descent from around Strangways, Anna Creek and Macumba stations. They were intermarried with Lower Southern Aranda from north of Macumba Station, Antakarinja from further north east, and Wangkangurru from the west.

8 Proeve 1945:22-3.

9 cp. Hercus 1977:53.

10 For further details see Turner 1936. 
language and any regular contact with Aboriginal relatives and their way of life. The UAM also established missions at Ooldea, Swan Reach, Nepabunna and Gerard. These are all discussed by Gale 1964 .

In 1938 the UAM wrote to Mr Wood and Mr Warren for permission to open mission work on Finniss Springs Station. According to mission records the station owners were reluctant. ${ }^{11}$ Following a visit from Pastor Erskine, the acting president of the UAM, a letter was received from F.D. Warren in 1939 consenting to the opening of a mission at the station. ${ }^{12}$ There followed approximately twenty years of mission education on the pastoral station.

In the 1940s the average school attendance was thirty. Some of the families with children attending school were Arkaringas, Warrens, Strangways, Stuarts, Dodds, Merricks, Buzzacotts and Murrays. In the camps which were on both sides of the creek there were about seventy-five Aboriginal people. At times it was well over 100 people and sometimes about 200 people on Finniss. By the end of 1942, sixteen square miles was set aside from the station and became the property of the UAM. On this, with the help of children, parents and station hands they built a school, a church, a mission house, a store, a small hospital room, a 'free lite' for wind generated power, and two below ground water tanks. This is the period covered below in Reg Dodd's childhood memories.

Gradually as more children moved away from Finniss Springs the school population dwindled. In the mid-fifties with the death of Francis Dunbar Warren and the gradual movement of more people to Marree for work the school at Finniss ceased. ${ }^{13}$ The United Aborigines Mission established a presence in Marree in 1965 replacing the mission services at Finniss. ${ }^{14}$ Children then attended the local state school.

Reg Dodd one of Francis Dunbar Warren's grandsons and Chairman of the Marree Arabanna People's Committee, recalls his own education and early life on Finniss Springs as follows.

11 Mattingley 1988:250 quotes lack of water as the reason given. Despite repeated requests I have not been able to gain access to these records now presumably housed in Melbourne. This was no doubt one genuine reason for reluctance. Another would have been initial suspicion of a mission presence. The missionaries subsequently sent to Finniss with few exceptions were very pleasant and kind people. Friendly and helpful relations were established and generally maintained between station and mission throughout this period. See Pearce n.d. Warren himself had strongly desired education for his children since c.1920 according to his eldest living daughter Merna Merrick (personal communications). He was very pleased that his youngest children and grandchildren could receive this without leaving Finniss. In return he was evidently prepared to accept a mission presence even deeding them part of the station.

13 Gale 1964:113 \& 370, discusses problems faced by the missions at Finniss and elsewhere.

14 Mattingley 1988:252. 


\section{ABORIGINAL HISTORY 1989 13:2}

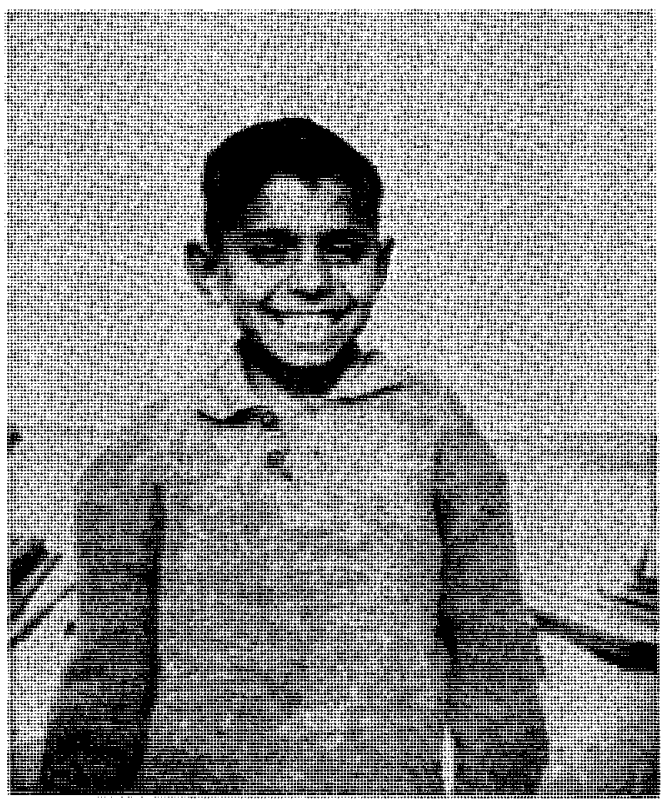

Above: Reg Dodd, 1949 [Andrew Pearce collection, negative held by Aboriginal Heritage Branch, Dept of Environment and Planning, SA]

Below: From left: Norm Ward, with daughter Sharlee in lap, Jean Wood nee Arkaringa, Merna Merrick, nee Warner (rear) Gladys and Reg Dodd with grandson Waylen; on the verandah of the 'new' house built in the 1930s after Wood won the lottery, at Finniss Springs Station, via Maree, S.A. [Photograph by Jen Gibson, Easter 1988]

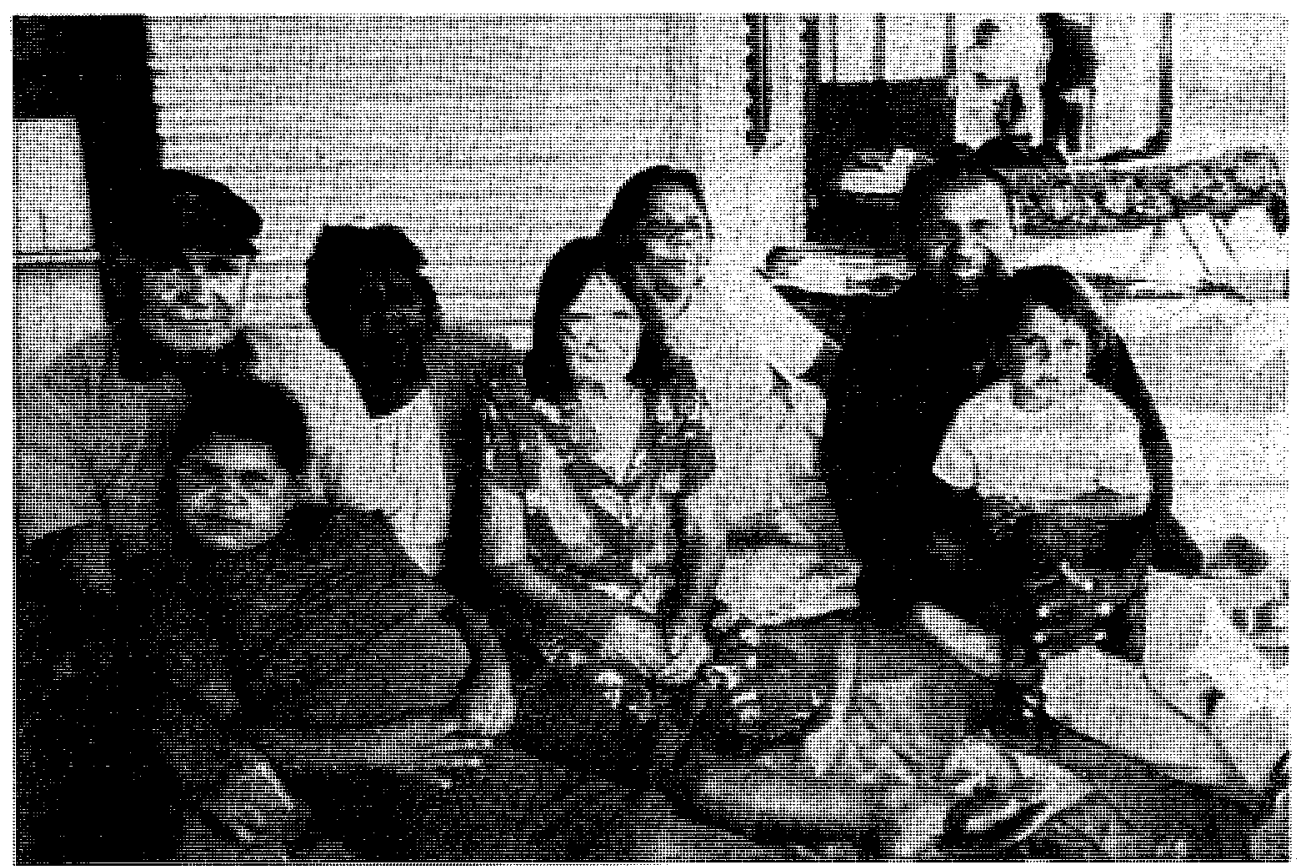




\section{Learning Times}

I was born on the 29 November, 1940 on Finniss Spring. You remember things that happened when you were small, in your childhood days, there's so much you can say but you don't know where you can start. Well going back as far as I can remember is my school days at the Finniss.

I'm Arabana. My old man was Lower Aranda. ${ }^{15}$ I go under the name Dodd even on my birth certificate. The certificate is Dodd but my old man's name was Alan Buzzacott. He probably would have had an Aboriginal name but I wouldn't know. Mum, well her mother was Arabana and her father was an old Scotchman, Francis Dunbar Warren. My grandfather's father was titled the Honourable John Warren. He came over from England. You'll find out that all these Murray River and Barossa Valley Warrens are tied in with the Warren family. I think the great grandfather owned the first brewery on the banks of the Torrens. ${ }^{16}$ That's on my mother Amy Buzzacott's side [nee Warren].

Mum was born in a big family. She was married to Thomas Dodd before. I would say just off the top of my head there would have been about a dozen of us in the family. Percy Dodd he was the oldest. He passed away now. There's Percy, Norman, Don, Arnold, Ronnie, myself and Philip, Kenny, Kevin and Trevor. That's not in order. Then there's three girls. One that passed away now. That's Sissy. And then Nancy and Esther. Most of the Warren families they were really big families.

My mother was born on Anna Creek Station and my father way up out of Alice Springs somewhere. Anna Creek was Arabana country. I've been told by some of the older people that the old grandfather Francis Dunbar Warren had shares in Anna Creek Station and I think someone older used to own Anna Creek Station. After John Warren's death they sold Anna Creek. ${ }^{17}$ By this time my old grandfather had three daughters, Amy my Mum, Mona, and Flora and two sons Arthur and Angus.

The government was taking these kids away, off their parents, and taking them into homes. That's what they used to do in the past. Well, he could see this was going to happen so he packed up his gear and came down to the Finniss from Anna Creek. There's so much that happened, there's a lot of stories in between. To cut a long story what happened he set up the mission. He set up a mission there and a school, a hospital and a shop. There were big mob of families all educated there, a big school. That's part of the Arabana family tradition.

The Aboriginal people built the place up themselves with assistance. I think they got a carpenter up from down south and they built their own concrete bricks and built the house themselves. They made the bricks, they built the church and built the school. I

15 Arabana like the associated Wangkangurru and Diyeri peoples and the Adnyamathanha in the Flinders Ranges traced descent matrilineally having a moiety system of social organisation.

16 In his typescript 1930, John Warren the elder brother of F.D. Warren (Reg's grandfather) documents his grandfather John Warren's arrival in South Australia in 1838 and his establishment of the first brewery. He also mentions an early English family title now lapsed. This detailed documentary source provides support and expansion for Reg's own oral memories at various points.

17 John Warren (F.D. Warren's father) died in 1914 ibid. 
remember when I was a kid going to school - of course I was only small then - I remember hearing this bloody dynamite going up and all these rocks coming out of the sky. 18

\section{Drought and Flood}

Through the drought years there wasn't any permanent drinking water there. ${ }^{19}$ The well was salt water and you could wash and cook in it. They used to cart water in a hundred gallon tank in an old two-wheeled dray the station had pulled by three horses. They used to cart it from about fifteen miles. There was an old pond soak. Then they would go back to the station. You'd have a shaft and have one horse in the shaft and one horse on either side. The blokes would go off from there. It would probably take all day to go from the station to the soak, fill up with water and then you'd have to come back to he underground tank.

One of those underground tanks they used to call 'Mr Nelson's tank'. The other one was the station tank and the other one was Mr Pearce's tank - just from the names. You had the station tank from the station, then you had Mr Nelson's tank and then Mr Pearce's tank. The first one was probably made in Mr Nelson's time. That's how the old people would have referred to it, 'Go and get water at Mr Nelson's tank.' I remember that. I remember they all used to cart water from there. I used to carry two ordinary four gallon kerosene buckets on a yoke from there back down to where we were living. Ordinary four gallon buckets, kerosene buckets. I thought I was really Samson carrying them. Probably I was around about ten, I couldn't put a date to it. You were always working all the time. You were doing that even at a small age. You tend to build up strength all the time. It was a really good life. Great!

Sometimes you'd get droughts. What would happen then the tanks would go dry. Then half the people would go from there and walk from Finniss over to the soak fifteen miles. They would live there until such time as it rained and the dam would fill up again. Then you would go back to the station.

As a kid I remember we were there with Mrs Strangways. Then we lived there for ages till the rain. We got a bit of flour and jam and sugar and tea that's all. Apart from that you lived off the land. We didn't go to school. That would have been the families that didn't have any bun cart to cart water. There would be the people that worked on the station, they would remain on the station. Their husbands or their sons worked on the station, there was no need for them to go. They need to stay there on the station and do the work. The people that didn't, they would move over to the soak. There would be thirty or forty people or more. Then they all had horses or dogs and whatever animals to water. They were good times. They were learning times.

18 Arthur Warren, Reg's uncle, recalls participating in the construction of the mission buildings. 'I was the one that worked on that church [making] bricks and that roof. I put that roof on. Me and old Thompson.'

19 Water was always a problem at Finniss. The average rainfall was only 500 points. The only permanent water came from a thirty metre well put down by Warren and Woods just prior to moving in. When the mission started, new wells also called tanks had to be made. These were named after the missionaries present at the time they were constructed. 


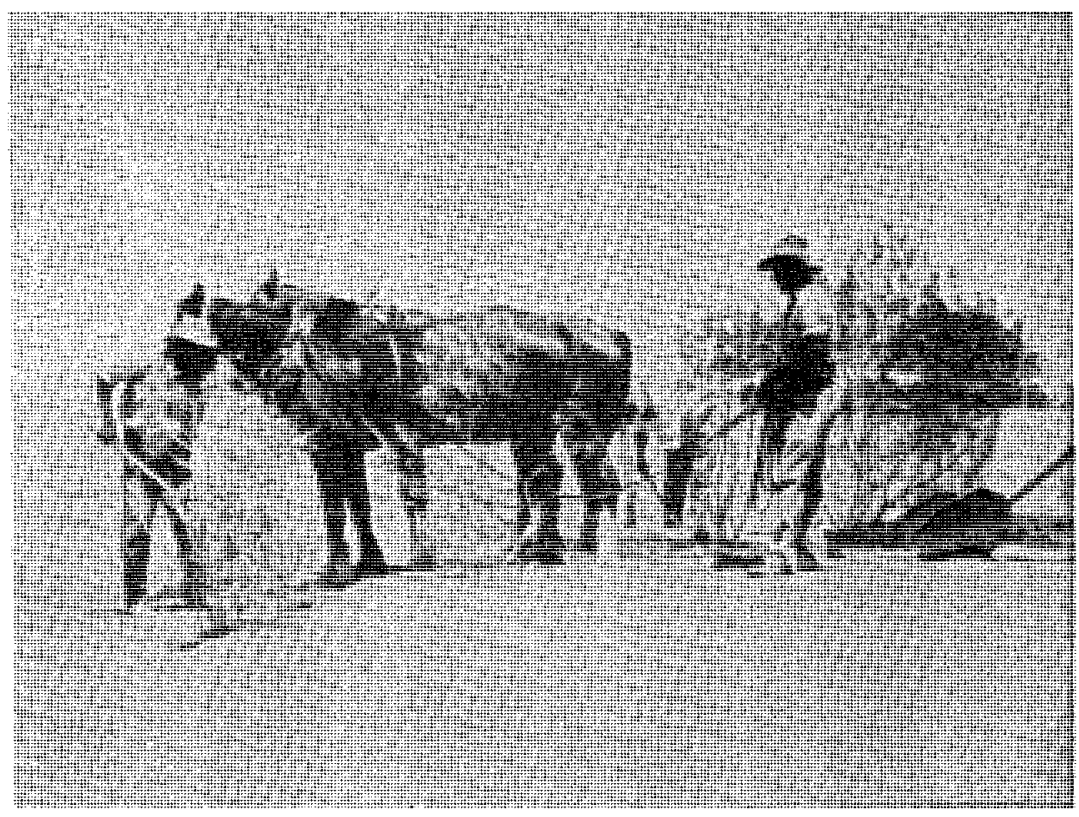

'But 1944 was awful - drought'

[Andrew Pearce collection, regatives held by Aboriginal Heritage Branch, Dept. of Environment and Planning, SA] 


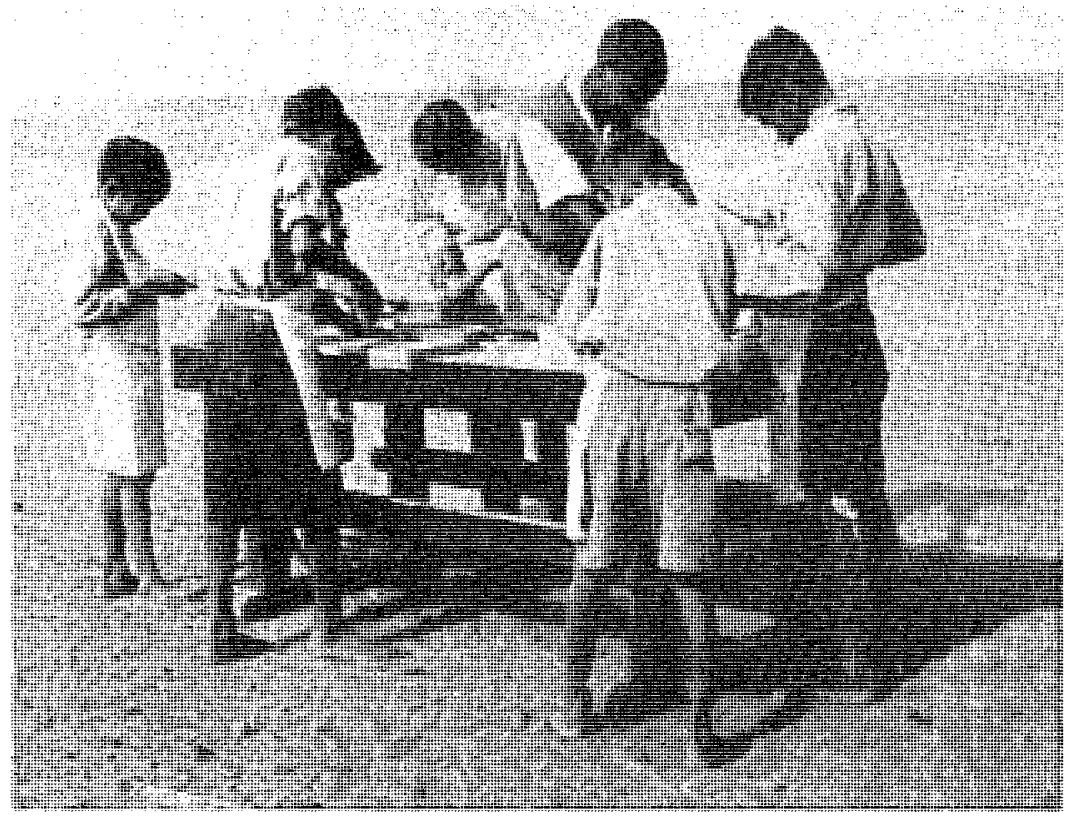

'Woodworkers', 1945

[Andrew Pearce collection, negatives held by Aboriginal Heritage Branch, Dept. of Environment and Planning, SA] 


\section{LEARNING TIMES}

Mrs Edie Strangways was strict. ${ }^{20}$ My God she was really strict. But now I look back at it she knew what she was doing. You would be allocated work. You had to wash up or chop wood or rake the yard or something like that. You had to do your work - no argue the point or back answer! It was really good. She was really strict.

I remember when they were going. They were starting to walk off. I was bellowing my eyes out to go with them. You walked and you didn't have anything. Your swag on your back and your billy can and tucker. The old people wouldn't let me go there for awhile but I cried so much they agreed to let me go. So I went [with] Mrs Strangways and stayed with her. Most of the time I stayed with her family anyway. All our family were fairly close. You were classified as brothers and sisters and whatever may be. You just had that inbuilt thing of Aboriginal people.

I went back there early in 1987 . We had built these little humpies. I had a look at the area where we were camping. You could still see this complete circle of round stones where the humpies used to be. When you camp you put out the stones and that to get a better camping area. That's over where the soak was. I would say it's probably about ten miles not fifteen. It would be about four or five say six miles at the most off the main road.

That was the drought years when you had no water but then you had floods too. I remember when we had the floods. Jingo! There was water. There are some good photos of that. Pearce was here then when we had the big floods and all the people shifted from where they were camping in their humpies. They all went into the church and stayed in the church. Apart from old Arthur most of the other people related to old grandfather lived around that area. The other people lived on the other side of the creek. ${ }^{21}$ Old Arthur lived there too. There was a good few like old Pop Strangways' brother, they stayed there. Some of the old old, really old people they lived on the other side of the creek too but they still had that close tie. All the Aboriginals would cross over.

\section{Arabana Life}

The marvellous thing about it, you'd be sitting there and then somebody would come along and without even talking they must have communicated. ${ }^{22}$ the visitor wanted. It was just one of those things Perhaps they'd lived together that long and they knew. But I always tend to think it's mental telepathy. They contact somewhere. But they always

20 Mrs Edie Strangways mentioned by Reg was a Lower Southern Aranda woman who married Henry an Aragana man and one of four brothers taking their sumame from old Strangways station. Their mother was old Tilly from Macumba way [personal communication Doreen Stuart].

21 The mission buildings were across a small tributary creek bed from the station homstead. The houses of the families with children attending school and Bralda's own camp were on the mission side. The older Aboriginal people lived on the opposite side of the main creek to both the station and the mission. This threefold physical division reflected social divisions within the community between the older more traditional Aboriginal people, the two station owners at the homestead and the mission's 'sphere of influence'.

22 This group identifies itself as predominantly Arabana. Traditionally the area of Finniss Springs belonged to the Kwiyani people. As indicated above many people were of mixed descent. 
taught us that you always fed the other people before you fed yourself. It was always a thing with the old people. You always gave the visitor the food or whatever it may be, a drink of water, but whatever you had there, you always gave. You were the last. It was just that way.

There was so much they had in good will. There was none of this thinking of yourself before the other person. All sharing. I think it was there all the time. It was that close thing. That's why I think most of the older Aboriginal people have taught that. One person didn't have more than the other person. They all had equal shares or whatever it may be. That's how it was. A lot of people nowadays call it communism. But that's how it is. There were never any problems there no problems at all.

There is so much! You go out there and start talking things just come back to you normally, you can relate to it a lot easier. "This is what happened to me over there. This is the time this tree fell off here.' Things like that. In the old days you would never light a fire or a smoke without something being wrong. Seeing the smoke they would know straight away there was problems there. Somebody would ride up on a horse. It happened a hundred times. Yes, you could be bogged or you'd broken an axle or a puncture or something. With the smoke, that's why they lived by smoke signals. There was always something, some reason for it.

On weekends, it used to be Saturday morning, we'd go to the dam where all the tanks are, to do the washing. We'd get a four gallon bucket, take it down there and set up a fire. This was when there was plenty of water in the dam. We'd fill up the four gallon bucket, light a fire and get the water boiling. Then you'd get a bit of camp sheet, like everyone used, for the purpose of washing. You'd dig a hole in the ground then put a camp sheet over it, make a hollow, put your water in it then wash your clothes in it. Wash our head and that in it. Just tip the water out when you'd finished and put the camp sheet back in the bush. That was rain water. They'd experiment too, like in the good season you could dig in the creek there and you'd soak water from the creek. That sort of thing happened. All those things you look back on.

When the dam did go dry what they used to do was they'd have these barrows, the horse used to pull. One bloke would hold the old hand plough. The other bloke would go on the plough. One horse would pull it. We'd drive the horse along and the men would hold the thing. We were only kids of seven or eight and you'd have the plough. Once you'd dug it up so much you'd disconnect, take the horse from the plough and hook him on to the scoop. Then the same thing would happen. You'd tip it up on the bank. You'd go from daylight to dark, you'd work. Then when you got rain you'd have more water in your tank.

The biggest thrill used to be when the hawker came along in the old camel cart. We didn't use camels - more horses and bun cart. Old Jack Clark, he was an old white bloke, he was a good friend of the old grandfather. He used to come up every so often to visit. Say once every twelve months. He'd bring these lollies, liquorice and those brown toffees. He used to be an old dogger from the other side I think from Oodnadatta or somewhere.

Then you'd get the hawker, old Harry Monsoor. ${ }^{23}$ He'd come along. Old Afghan hawker. He'd have this big old white van, he'd drive. It was probably one of the first trucks to be going in the area. He'd have all his cloves and almonds and lollies. A big bag of

23 For further details see Rajkowski, 1987:151-2. 


\section{LEARNING TIMES}

almonds one shilling. I think he had some growing at Copley. He'd have these wheat bags full of them. Two bob and we'd get a big pack of that. We would tend to spend it if they were around on balloons or chewing gum. The old people used to say they were no good because balloons will be blowing up, it's a waste of money. They didn't like you chewing gum. I suppose it was messy and you chuck it around. P.K. chewing gum, Arrowmint, Juicy Fruit. Oh!

There were no ceremonies around Marree. Even up at Finniss there weren't too many there. Oh there would have been in the past. More or less I think you had the Lower Aranda and the Antakarinja and the Arabana and the Diyeri, Wangkangurru and Kwiyani. I can't define that southern boundary because I don't really know. Some say it's here and some say it's up at Curdimurka. Apparently somewhere along the line the Kwiyani is tied into the Arabana some way. Apparently one of the old blokes married a Kwiyani lady and that's the sort of tie up the Kwiyani and the Arabana. Adnyamathanha, that's only a flash name for them, the Kwiyani. I think they're the same.

They used to make the old houses out of the old bitumen or tar drums. There used to be a lot of tar around in those days. They used to get the drums and we'd cut the ends out of them and split them down and flatten them. It was a horse trough. Any tin at all that you could make flat. Then you got your sides or make a bough shed and just a dirt floor. I remember we got an Army tent from somewhere. It was nearly as big as a house, I thought it was a palace.

But still an all you still wasn't happy [living indoors]. We'd still get our blankets, we probably had one blanket, two blankets or something and went and laid down on the outside. Most times only us kids slept outside because we'd yack all night. The greatest thing, sometimes you'd get about ten or fifteen kids lying around in a line and the game we used to play was 'Riddle me riddle what I can see.' It starts with 'A' and finishes with something or other. That was the great thing! Like the saucepan in the sky or a star or anything.

Although they weren't flash houses, they weren't even houses, just old bough sheds and that, I don't recall ever being ill or unhappy at any time. You could get up and walk for miles and miles. If you saw a rabbit you'd chase it until you got it. Sometimes the rabbit would knock up before you would then you'd get it, that's if it didn't go down a burrow or something. We would walk for miles and miles on end. You might grab a feed once a day or something. It was all right.The system they had out at Finniss you wouldn't get it anywhere else I would think in the world, the way it was set up. The people had their lives and they got the education and they lived their own [way]. The families were there anyhow. They weren't taken away by the Home, they were there. You've got your teaching and you had your family. Most of the other missions took the kids out of the homes and then placed them into Homes or whatever. When they lived in the mission they were living away from their parents anyhow. Even the mission at Oodnadatta, they'd take the kids out of their homes and they were living in the mission. They were restricted. Parents weren't allowed to go near them. But there you were living in your own homes. You could come and go as you pleased. Then you had the benefits of the towns say Port Augusta, you had your hospital and your shops and so on. The lot. 


\section{The Environment}

The seasons were different too. At certain times of the year Mrs Strangways would take us down the creek. We'd go down with old milk tins. We used to make them into billy cans. We'd go down there and pick these like sultanas they were of the wattle trees. At another time of the year we'd go out and get some other thing like mulga apples or those beans that grow. We call them aritji on the mulga tree. The mulga apple that was artigula. Then you had aritji that grew on the mulga tree too but that was different. There is a difference in the mulga trees. If you don't know the difference you wouldn't know.

I often go out now on my own. I get that urge to eat this stuff. I have that feeling that Aboriginal people must have Aboriginal food because their system is different to the European people. That's my belief. I might be wrong. You must have that real natural food to keep up whatever it may be inside. They must have had some type of protection against bacteria to counteract any sickness. That's my feeling. Although we look the same our system is different somewhere along the line. It's got to be because you are living on two different types of food. I always go out and have a good feed of bush tucker now and then.

It would be great if students and others could go out to the bush for a week. By setting up camps that could happen. Once the areas are set up you could approach schools or colleges or teachers and say 'We've got these areas set up for camps and you are interested in coming out and seeing Aboriginal tucker', or whatever it may be.

\section{Mission Influences}

Norm ${ }^{24}$ was telling me how at first they used to go to school in the tent. That was the first school. He knew Nelson. From Norm's age group - fifties getting close to sixty you would start to speak the European language and read and write. He would have been at the turming point from Aboriginal style to get a good education.

We used to have church in the mornings, Sunday mornings. We had to go to Sunday school. There was no release. If you weren't at Sunday school you were in for it. You were in for a hiding on Monday morning at school.

They'd teach you at school about Easter when Christ was killed and all that. Then you'd be looking forward to that because you'd get these Easter eggs. They were caramel eggs but two halves stuck together with caramel things. They probably bought them. Easter had this purpose and Christmas and so on.

That's what you were taught at Sunday school and church. You got a lot of respect from that too. You'd go to Sunday school and you'd have a little booklet and you'd get these little stamps you'd have to stick on certain areas. Something about shepherds shepherding sheep and you'd paste that onto that there. This area would be left for the stamp. You'd paste your stamp and on the bottom you'd have the story relating to that.

I remember Jean Wood's oldest sister Nora getting married at the church. She married Hector Murray. Then they took off on a honeymoon in an old buggy. They went down the creek. That was a big occasion. Everyone came up. They were married at the church. $\mathrm{Mr}$

24 Norman Wood is Reg's eldest living half-brother. His father was Bill Wood the costation owner and his mother Amy was F.D. Warren's eldest daughter. 


\section{LEARNING TIMES}

Pearce was a Justice of the Peace. I think he was Church of England or Methodist. The teaching was all combined.

He used to be able to take out teeth or stitch up your legs or whatever it may be. I remember once climbing up a tree and I ripped my leg [right thigh - there is still a scar]. Esther [Reg's oldest sister] carried me back to the camp and took me round and they stitched it up. He wouldn't have had any needles for anaesthetic. The tree's not there now but I know exactly where it was It was only a couple of years ago that it was washed down or pulled down for firewood. Mr Pearce used to rip out teeth, he could do anything.

He had the set-up and he was in contact with the Broken Hill base by radio on the pedal wireless. Broken Hill was the flying doctor base. It used to service all those stations. Even Muloorina Station up until recently, they used to service that. If someone got hurt or sick you'd be on the pedal wireless. The plane would come over, a double winged thing. You didn't have any contact at all with Alice Springs. That was all fairly well isolated up in that area.

\section{The move away from Finniss Springs.}

That time [when I was growing up] on Finniss there were more Aboriginal people than in Marree. You had to be on a station to get that government ration. If you weren't on a station you wouldn't get any government rations. Then most of the Aboriginal people, like stockmen were people who worked on the stations. In the early days I think the only person who went away to work was Angus Warren. He was a shearer. People started to move away searching for employment. [One man] went to Marree as a fettler then others followed. They all had big families and they had to go out looking for work. As times were changing they were searching for work on the railways as fettlers and so on. Towards the end the only people left were like Stan's [Warren] direct sons of the old bloke.

You finished school at fourteen and got your Progress Certificate. I was living with my aunty because my old man had got a job as a fettler on the railways and he had shifted [to Marree]. You had to go and look elsewhere for jobs because the family was growing all the time.

How Alan Buzzacott, my father came to get the job was we used to travel round on this little bun cart pulled by two horses. We used to go up to Stuarts Creek or come down here [Marree] during school holidays. We were camped up at Curdimurka by the tank and the senior road master Mr Des Dunning came up. He was passing through and he used to patrol the line to Oodnadatta or William Creek. We were all sitting under the tree there. He pulled up and had a talk to us, talked to the old man. We were only kids. Whether the old man asked him for a job or he said if the old man wanted a job, 'You go down to Marree and tell the chap in charge there that I gave you a job fettling. You start there as soon as you get there.' So, he worked on the railway.

He came down to Marree then. There were four younger boys younger than I was. I'd finished at fourteen so he came in here and he got the job and he was given a house, an old navvy cottage they stayed in. Then from there they shifted to a house in the back there and the kids went on to school here.

That's when I came in here one day and the bloke from Stuarts Creek came in a couple of days after and picked me up. He took me out to Stuarts Creek. That was my first job. Oh, I'd been working a couple of days as a butcher's bloke working there. They had a hand 
to put a couple of fences up here. I wasn't taken in to the fettler's job. I was only as skinny as a boomerang.

So this bloke turned up. He was Cliff Warren's father Roy Warren. The old man came back in here and said 'Right, pack your swag an you're going with him.' So it was hard on me. We got back to Stuarts Creek. I woke up next morning and all these Antakarinja blokes were around me. I couldn't even talk language then. But they were really good to me. I stayed there for about five years I think working on Stuarts Creek and Anna Creek. My language was mostly Arabana. I was just sitting around and these other blokes were talking Antakarinja. I couldn't understand the language but you soon learn to pick it up.

Well Stuarts Creek is only an outstation for Anna Creek. I was there for about five or six years and then I came back down here. I did one droving trip to see what it was like with Arnold my brother. He had a droving plant. We went through to Queensland. Then I came back here and got a job on the railways and that was it. I stayed on that job right through till they said we had redundancy on the 15 February 1986 . You can say twenty-five years I worked transshipping. I worked on the same thing all the time. I could have been transferred anywhere. I could have gone anywhere I wanted to go but with this community setup ${ }^{25}$ but I thought I had more to do here in Marree.

\section{Finniss In Retrospect}

I left [Finniss] in 1954. When the old [grandfather] passed away [later] in the 1950s that was a tragic blow. He was a key person, holding the community together. Then the people went away. He was the salt of the whole thing that held the community together. Everyone loved him. He wanted to be buried there. I wasn't there during the last weeks or months. Apparently he was suffering towards the end and he just wouldn't go away. He wanted to stay there with his people. He didn't go away.

He could foresee that as in every family business there is always some dispute which did happen. As a kid I remember there used to be no blues or ill feeling in the family at all. Not the family, the whole community. There was no trouble. I think he wielded a steel hand and he controlled them fairly well. I remember he liked working with the station, he'd have one bloke to do one job and that was his responsibility. Say he used to look after the sheep. Then on the other hand he'd have one bloke, his responsibility was to look after the men working the cattle. Then he'd have one just training his race horses. Then he'd have one doing the mechanical work.

As I recall my early childhood memory of growing up on Finniss Springs mission station I realise how fortunate I was. I was living in an Aboriginal environment and sharing with my tribal relatives our traditional culture. I was also taught by the missionaries the European life style and culture. I experienced the changing of Aboriginal tradition towards the European life style and living. Many of our Aboriginal children who were removed from their families and Aboriginal environment and placed in homes were isolated from any Aboriginal involvement losing their Aboriginality.

25 In 1987 Reg worked for the state government's Department for Community Welfare at Leigh Creek. 


\section{LEARNING TIMES}

\section{BIBLIOGRAPHY}

Basedow, Herbert. 'Report upon the Third Medical Relief Expedition among the Aborigines of South Australia, 17 June 1921', unpublished, South Australian archives [GRG 23].

Gale, Fay. A study of assimilation: Part Aborigines in South Australia. Ph.D. Thesis Univ. of Adelaide 1964, Libraries Board of S.A. Adelaide.

Gerard, A.E. History of the UAM. United Aborigines Mission, Adelaide, 1945.

Gibson, Jen. in press Molly Lennon's Story: That's how it was. Dept. of Environment and Planning, Adelaide, 1988.

Hercus, Luise. 'Tales of Ngadu-Dagali, Rib-bone Billy', Aboriginal History, 1 [1] 1977:53-76.

Kwan, Elizabeth, ed.Living in South Australia: A social history vol. 2, After 1914. South Australian Government Printer, 1988.

Mattingley, Christobel and Ken Hampton (co-editors) Survival in our own land - Aboriginal experiences in South Australia since 1936 told by Nungas and others, Adelaide, 1988.

Pearce, Andrew. Brown boys and boomerangs a series of Aboriginal stories. UAM, Adelaide, n.d.

Pearce, Howard. 'Killalpaninna Mission Station, notes and documentation relating to Killalpaninna Mission Station Cooper Creek, South Australia'. S.A. Aboriginal and Historic Relics Unit, 1980.

Proeve, E.H. Scattered homeless flock, mission among the Dieri. Point Pass, S.A. 1945.

Rajkowski, Pamela. In the tracks of the camelmen - outback Australia's most exotic pioneers. North Ryde, NSW, 1987.

South Australia: Protector of Aborigines Annual Report 1908, State Library of South Australia.

Turner, Violet E. Pearls from the deep. United Aborigines Mission, Adelaide, 1936.

Warren, 'Four John Warrens 1838 - 1930, recollections of pioneering in Australia by Number three'. Typescript, lodged with National Library Canberra ms 6120, 1930. 